\title{
Pentacoordinate Silicon Complexes as Precursors to Silicate Glasses and Ceramics
}

\author{
Pallavi Kansal ${ }^{\star}$ and Richard M. Laine*
}

Department of Materials Science and Engineering, University of Michigan, Ann Arbor, Michigan 48109-2136

The recent discovery that pentacoordinate alkali glycolato silicates such as monomeric $\mathrm{MSi}\left(\mathrm{OCH}_{2} \mathrm{CH}_{2} \mathrm{O}\right)_{2} \mathrm{OCH}_{2}-$ $\mathrm{CH}_{2} \mathrm{OH}$ or dimeric $\mathrm{M}_{2} \mathrm{Si}_{2}\left(\mathrm{OCH}_{2} \mathrm{CH}_{2} \mathrm{O}\right)_{5}$ (where $\mathrm{M}=\mathrm{Li}$, $\mathrm{Na}, \mathrm{K}$, or Cs) can be synthesized directly from $\mathrm{SiO}_{2}$, ethylene glycol, and MOH suggests that these compounds may serve as useful, inexpensive precursors to alkali silicate glasses or ceramics, either by sol-gel processing or by simple pyrolysis. We report here studies on the chemical changes and phase transformations that occur during the pyrolytic transformation of these compounds to ceramic and glassy materials. The evolutionary processes encountered as the materials are heated to selected temperatures were followed by $\mathrm{X}$-ray powder diffraction, diffuse reflectance infrared Fourier transform spectroscopy (DRIFTS), and thermal analysis techniques. In general, the crystalline compounds oxidatively decompose at temperatures above $300^{\circ} \mathrm{C}$ to form amorphous materials. At higher temperatures, the line compounds $\mathrm{M}_{2} \mathrm{Si}_{2} \mathrm{O}_{5}$ begin to crystallize. During the transformation process, ligand oxidation forms $\mathrm{CO}_{2}$ and $\mathrm{H}_{2} \mathrm{O}$, which react with the alkali metals to form small amounts of carbonates as seen by DRIFTS. At higher temperatures, the carbonates decompose with coincident formation of the primary crystalline phase, except in the case of the potassium compound, which exhibits some phase segregation.

\section{Introduction}

W E HAVE recently discovered that it is possible to react silica gel, fused silica, and even beach sand with alkali metal hydroxides, in excess ethylene glycol, to obtain pentacoordinate, anionic silicon complexes as illustrated in reactions (1) and (2): ${ }^{1-5}$

$$
\begin{aligned}
& \mathrm { SiO } _ { 2 } + \mathrm { MOH } + 3 \mathrm { HO } \longdiv { \mathrm { OH } } \underset { \approx = 2 ( \mathrm { HOH } ^ { \circ } \mathrm { C } } { \stackrel { 3 \mathrm { H } _ { 2 } \mathrm { O } } { \longrightarrow } } \\
& \mathrm{M}[\mathrm{O} \mathrm{O}]_{\mathrm{O} i}{ }^{\mathrm{O}} \widehat{\mathrm{O}}_{\mathrm{O}}{ }^{\mathrm{H}}
\end{aligned}
$$$$
\mathrm{M}\left[\left[\begin{array}{l}
\mathrm{O} \\
\mathrm{O}
\end{array}\right] \mathrm{Si}^{\prime}{ }^{\mathrm{O}} \mathrm{O}^{\prime} \underset{{ }_{170^{\circ} \mathrm{C}}}{\stackrel{-\left(\mathrm{HOCH}_{2} \mathrm{CH}_{2} \mathrm{OH}\right)}{\longrightarrow}}\right.
$$$$
\left.\mathrm{M}_{2}\left[[\mathrm{O}]_{\mathrm{O} i}, \mathrm{O}_{\mathrm{O}-\mathrm{Si}}^{\mathrm{O}} \mathrm{O}_{\mathrm{O}}^{\mathrm{O}}\right]\right]_{2}
$$

$\mathrm{M}=\mathrm{Li}, \mathrm{Na}, \mathrm{K}, \mathrm{Cs}$

\footnotetext{
L. Klein-contributing editor
}

\footnotetext{
Manuscript No. 194379. Received July 19, 1993; approved November 22, 1993 Supported by the U.S. Army Advanced Materials and Technology Laboratory through Contract No. DOD-C-DAAL04-91-C-0068 and by the Army Research Office through ASSERT Grant No. DOD-G-DAAL03-92-G-0053.

"Member. American Ceramic Society.
}

We also find that reaction of $\mathrm{SiO}_{2}$ with alkaline-earth metal ( $\mathrm{Mg}, \mathrm{Ca}, \mathrm{Ba}$ ) oxides, in excess ethylene glycol, leads to very novel, hexaalkoxy dianionic silicates: ${ }^{6}$

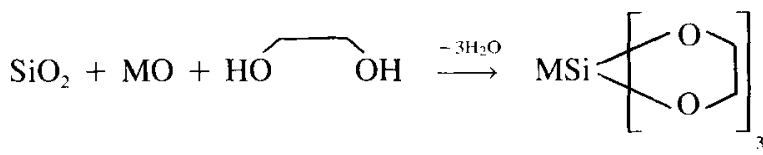

$$
\mathrm{M}=\mathrm{Mg}, \mathrm{Ca}, \mathrm{Ba}
$$

Although related pentaalkoxy silane complexes have been prepared before, ${ }^{7-12}$ prior syntheses were always based on tetraethoxysilane (TEOS) or a related compound rather than directly from silica.

The facile synthesis of the pentacoordinate silicates directly from $\mathrm{SiO}_{2}$, combined with atomic mixing of the alkali metal with $\mathrm{Si}$, suggests that these compounds might be useful for processing alkali silicate glass or ceramic powders. In addition, because the glycolato silicates are readily transformed into theologically useful polymers, ${ }^{1}$ they may provide access to coatings, films, and fibers. Thus, the objective of the work reported here is to develop a basic understanding of behavior of the dimeric compounds, $\mathrm{M}_{2} \mathrm{Si}_{2}\left(\mathrm{OCH}_{2} \mathrm{CH}_{2} \mathrm{O}\right)_{5}(\mathrm{M}=\mathrm{Li}, \mathrm{Na}, \mathrm{K}$, and $\mathrm{Cs}$ ), during pyrolysis in air. These studies delineate the effects of temperature and time on the decomposition and crystallization processes that occur as the above pentacoordinate glycolato silicates are pyrolytically transformed into crystalline and/or glassy alkali silicates. The results of these studies establish a baseline for further studies wherein ligand substitution provides processable polymer precursors.'

\section{Experimental Work}

\section{(1) General Procedures}

All air- and moisture-sensitive materials were handled using standard Schlenck techniques or in an inert atmosphere of a Vacuum Atmospheres Model No. MO40-2-Dri-Lab glove box (Vacuum Atmospheres Company, Hawthorne, CA). All chemicals were purchased from standard vendors and used as received, except for ethylene glycol and acetonitrile, which were distilled under $\mathrm{N}_{2}$ from appropriate drying agents before use.

\section{(2) Syntheses}

A general synthesis for alkali glycolato silicates is described below. Further details concerning the syntheses of the materials studied here are reported elsewhere. ${ }^{13}$ Typically, 1 equiv of metal hydroxide is reacted, with 1 equiv of silica, in excess ethylene glycol with continuous distillative removal of water, followed by cooling and precipitation of pentacoordinate glycolato silicates.

A mixture of $0.5 \mathrm{~mol}$ of $\mathrm{MOH}(\mathrm{M}=\mathrm{Li}, \mathrm{Na}, \mathrm{K}$ or $\mathrm{Cs}), 0.5$ mol of $\mathrm{SiO}_{2}(30 \mathrm{~g}$, high surface area), and $500 \mathrm{~mL}$ of ethylene glycol is placed in a $1-\mathrm{L}$ flask. The mixture is heated to $\approx 200^{\circ} \mathrm{C}$ under $\mathrm{N}_{2}$ with constant mechanical stirring. The silica and alkali hydroxide readily dissolve with continuous distillation of ethylene glycol and removal of water formed as byproduct. The reaction goes clear and is complete in 1-2 h; when $300-400 \mathrm{~mL}$ of 
glycol have distilled off, the clear solution becomes increasingly viscous and the crystalline product starts to precipitate out. The precipitate and the solution are allowed to cool overnight. On cooling, a large solid mass forms that is broken up with a spatula. The product is filtered and washed with $300 \mathrm{~mL}$ of distilled $\mathrm{EtOH}$ or acetonitrile to remove ethylene glycol. The chemical analyses, listed in Table I, show the products to be monomers except for the sodium glycolato silicate which precipitates out only as the dimer.

The monomeric alkali glycolato silicates all convert to their respective dimers, on heating at $170^{\circ} \mathrm{C}$ for $4-5 \mathrm{~h}$, under vacuum. The products are somewhat moisture sensitive and also react readily with $\mathrm{CO}_{2}$. The glycolato silicates used in these studies were always kept stored in a glove box ( $\mathrm{N}_{2}$ atmosphere).

\section{(3) Pyrolysis}

Samples of the individual precursors were pyrolyzed in a single-zone, Lindberg (Model No. 58114, Watertown, WI) tube furnace, equipped with a Eurotherm programmable temperature controller (Model No. 818P, Northing, England). Samples $(1--2 \mathrm{~g})$ were packed in an alumina boat and placed inside a ported quartz tube, inside the glove box. The quartz tube was then sealed with a cap, taken out of the glove box, inserted into the furnace, and connected to a supply of dry, compressed air. The individual samples were heated at $10^{\circ} \mathrm{C} / \mathrm{min}$ in flowing (synthetic) air to selected temperatures $\left(300^{\circ}, 500^{\circ}\right.$, $700^{\circ}$, and $900^{\circ} \mathrm{C}$ ) and held there for $2 \mathrm{~h}$. The pyrolyzed samples were unloaded inside the glove box and stored there. The pyrolyzed samples were not exposed to ambient atmosphere during the transfer process.

Note. Synthetic air is dry, compressed air. It is a mixture of $\mathrm{O}_{2}$ and $\mathrm{N}_{2}$, in approximately the same ratio as in atmospheric air $\left(\mathrm{N}_{2}: 77-80 \% ; \mathrm{O}_{2}: 20-22 \%\right)$ and is free of any $\mathrm{H}_{2} \mathrm{O}$ or $\mathrm{CO}_{2}$.

\section{(4) Characterization}

The phase transformations and chemical changes that occur during pyrolytic transformation of the precursors to amorphous and/or crystalline materials were characterized using powder $\mathrm{X}$-ray diffractometry (XRD), diffuse reflectance infrared Fourier transform spectroscopy (DRIFTS), thermal gravimetric analysis (TGA), and differential thermal analysis (DTA). Chemical analyses were performed by Galbraith Laboratories of Knoxville, TN.

\section{(5) $X R D$}

The XRD patterns were determined using a Rigaku rotating anode goniometer (Rigaku Denki Co. Ltd., Tokyo, Japan). Powder samples (100-200 mg) were (1) ground with an alumina mortar and pestle, (2) packed in a glass specimen holder, and (3) placed in the goniometer. Scans were continuous from $5-80^{\circ} 2 \theta$ at a scan rate of $10^{\circ} 2 \theta / \mathrm{min}$ using $0.05^{\circ} 2 \theta$ increments and $C u K \alpha(\lambda=1.542 \AA)$ radiation. The peak positions and the relative intensities of the powder patterns were identified by comparing with standard JCPDS files for characterization purposes. Powder diffraction patterns for the monomeric and dimeric silicates are listed in Table II.

\section{(6) DRIFTS}

The DRIFT spectra were recorded on a Mattson Galaxy Series FTIR 3000 spectrometer (Mattson Instruments, Inc., Madison, WI). Optical-grade, random cuttings of $\mathrm{KBr}$ (International Crystal Laboratories, Garfield, NJ) were ground using an
Table II. Powder Diffraction Patterns for Dimeric and Monomeric Glycolato Silicates

\begin{tabular}{|c|c|c|c|}
\hline \multicolumn{2}{|c|}{ Dimer } & \multicolumn{2}{|c|}{ Monomer } \\
\hline$d$-space & $I$ (rel) & $d$-space & $l(\mathrm{rel})$ \\
\hline \multicolumn{2}{|c|}{$\mathrm{Li}_{2} \mathrm{Si}_{2}\left(\mathrm{OCH}_{2} \mathrm{CH}_{2} \mathrm{O}\right)_{3}$} & \multicolumn{2}{|c|}{$\mathrm{LiSi}\left(\mathrm{OCH}_{2} \mathrm{CH}_{2} \mathrm{O}\right)_{2} \mathrm{OCH}_{2} \mathrm{CH}_{2} \mathrm{OH}$} \\
\hline 8.6653 & 100.0 & 7.0475 & 32.20 \\
\hline 8.1852 & 41.17 & 6.8837 & 84.52 \\
\hline 7.6885 & 36.76 & 4.4692 & 100.0 \\
\hline 4.4916 & 20.54 & 4.2369 & 16.12 \\
\hline 4.425 & 18.09 & 3.9056 & 14.84 \\
\hline 4.3605 & 18.88 & 3.6823 & 20.08 \\
\hline 4.2773 & 18.45 & 2.2073 & 13.18 \\
\hline \multicolumn{2}{|c|}{$\mathrm{Na}_{2} \mathrm{Si}_{2}\left(\mathrm{OCH}_{2} \mathrm{CH}_{2} \mathrm{O}\right)_{5}$} & \multicolumn{2}{|c|}{$\mathrm{KSi}\left(\mathrm{OCH}_{2} \mathrm{CH}_{2} \mathrm{O}\right)_{2} \mathrm{OCH}_{2} \mathrm{CH}_{2} \mathrm{OH}$} \\
\hline 8.1852 & 100 & 8.0734 & 95.84 \\
\hline 4.9241 & 1.90 & 6.9920 & 68.47 \\
\hline 4.8179 & 2.41 & 6.1038 & 85.98 \\
\hline 4.7539 & 4.09 & 4.8310 & 63.03 \\
\hline 4.037 & 1.17 & 3.9834 & 55.75 \\
\hline 3.9834 & 1.05 & 3.8554 & 100.0 \\
\hline 3.8971 & 1.93 & 3.3484 & 81.42 \\
\hline \multicolumn{2}{|c|}{$\mathrm{K}_{2} \mathrm{Si}_{2}\left(\mathrm{OCH}_{2} \mathrm{CH}_{2} \mathrm{O}\right)_{5}$} & \multicolumn{2}{|c|}{$\mathrm{CsSi}\left(\mathrm{OCH}_{2} \mathrm{CH}_{2} \mathrm{O}\right)_{2} \mathrm{OCH}_{2} \mathrm{CH}_{2} \mathrm{OH}$} \\
\hline 12.3534 & 6.94 & 10.1557 & 100.0 \\
\hline 8.6232 & 8.72 & 5.8243 & 30.05 \\
\hline 7.9647 & 5.46 & 4.0921 & 32.46 \\
\hline 7.5255 & 100.0 & 3.6748 & 90.26 \\
\hline 5.2267 & 25.55 & 3.4570 & 94.66 \\
\hline 5.1513 & 15.16 & 2.7569 & 51.91 \\
\hline 3.9484 & 6.47 & 2.4995 & 27.29 \\
\hline \multicolumn{2}{|c|}{$\mathrm{Cs}_{2} \mathrm{Si}_{2}\left(\mathrm{OCH}_{2} \mathrm{CH}_{2} \mathrm{O}\right)_{5}$} & & \\
\hline 10.9742 & 42.87 & & \\
\hline 10.4556 & 100.0 & & \\
\hline 10.2143 & 93.26 & & \\
\hline 3.7511 & 40.38 & & \\
\hline 3.4504 & 43.55 & & \\
\hline 3.4056 & 9.06 & & \\
\hline 3.3796 & 77.95 & & \\
\hline
\end{tabular}

alumina mortar and pestle and transferred to a flask. The $\mathrm{KBr}$ powder was vacuum dried for $0.5 \mathrm{~h}$ and then taken inside the glove box. DRIFT samples were prepared in the glove box by mixing $0.3-1.0 \mathrm{wt} \%$ of the sample to be analyzed, with the vacuum-dried $\mathrm{KBr}$.

Sample concentrations were kept below 1 wt\% to ensure adherence to Beer's law. The dilute samples prepared in $\mathrm{KBr}$ were subsequently packed firmly in the sample holder, leveled off at the upper edge to provide a smooth surface, and transferred to the FTIR sample chamber (brief exposure to air), which was flushed constantly with $\mathrm{N}_{2}$. A minimum of 64 scans were collected for each sample at a resolution of $\pm 2 \mathrm{~cm}^{-1}$. Diffuse reflectance peak positions were identified using a standard peak searching program.

\section{(7) Thermal Analytical Techniques}

TGA and DTA of the pentacoordinate silicate monomers and dimers were performed on a 2950 Thermal Analysis Instruments and 2910 Differential Scanning Calorimeter (TA Instruments, Inc., New Castle, DE), respectively. TGA samples averaging 10-15 mg were loaded on a platinum pan and heated

Table I. Chemical Analyses for Alkali Glycolato Silicates, $\mathrm{M}=\mathrm{Li}, \mathrm{Na}, \mathrm{K}$, and Cs

\begin{tabular}{lcccccc}
\hline \multicolumn{1}{c}{ Compound } & MW & Sample & $\mathrm{C}(\mathrm{wt} \%)$ & $\mathrm{H}(\mathrm{wt} \%)$ & \multicolumn{1}{c}{$\mathrm{M}(\mathrm{wt} \%)$} & $\mathrm{Si}(\mathrm{w} 1 \%)$ \\
\hline $\mathrm{LiSi}\left(\mathrm{OCH}_{2} \mathrm{CH}_{2} \mathrm{O}\right)_{2} \mathrm{OCH}_{2} \mathrm{CH}_{2} \mathrm{OH}$ & 216.16 & $\mathrm{Calc}$ & 33.30 & 6.06 & 3.21 & 13.00 \\
& & Expt & 32.50 & 6.20 & 3.03 & 11.20 \\
$\mathrm{Na}_{2} \mathrm{Si}_{2}\left(\mathrm{OCH}_{2} \mathrm{CH}_{2} \mathrm{O}\right)_{5}$ & \multirow{2}{*}{402.36} & $\mathrm{Calc}$ & 29.90 & 5.01 & 11.40 & 14.00 \\
& & Expt & 29.53 & 4.93 & 11.53 & 13.91 \\
$\mathrm{KSi}\left(\mathrm{OCH}_{2} \mathrm{CH}_{2} \mathrm{O}\right)_{2} \mathrm{OCH}_{2} \mathrm{CH}_{2} \mathrm{OH}$ & \multirow{2}{*}{248.32} & $\mathrm{Calc}$ & 29.00 & 5.28 & 15.70 & 14.00 \\
& & Expt & 28.26 & 5.06 & 14.85 & 13.91 \\
$\mathrm{CsSi}\left(\mathrm{OCH}_{2} \mathrm{CH}_{2} \mathrm{O}\right)_{2} \mathrm{OCH}_{2} \mathrm{CH}_{2} \mathrm{OH}$ & \multirow{2}{*}{342.16} & $\mathrm{Calc}$ & 20.72 & 3.63 & 39.38 & 8.58 \\
& & Expt & 21.06 & 3.83 & 38.84 & 8.21 \\
\hline
\end{tabular}


in flowing $\left(60 \mathrm{~cm}^{3} / \mathrm{min}\right)$ dry air, at $10^{\circ} \mathrm{C} / \mathrm{min}$ to $1000^{\circ} \mathrm{C}$. DTA measurements (sample sizes $\approx 20 \mathrm{mg}$ ) were performed using platinum crucibles, under a continuous flow $\left(50 \mathrm{~cm}^{3} / \mathrm{min}\right)$ of dry air, at $10^{\circ} \mathrm{C} / \mathrm{min}$ to $1200^{\circ} \mathrm{C}$. Calcined alumina (Aluminum Company of America, Pittsburgh, PA) was used as a reference.

\section{Results and Discussion}

In an effort to study the decomposition patterns of the pentacoordinate alkali glycolato silicates synthesized in reactions (1) and (2), samples of each of the glycolato silicates were first analyzed by TGA and DTA. The TGA results were used to verify chemical purity as defined by the expected and found ceramic yields. The mass loss as a function of temperature, when coupled with the events observed in the DTA, provided information concerning the decomposition patterns of the glycolato silicates and helped to define fixed temperature, bulk pyrolysis experiments. For example, most of the precursors decompose just above $300^{\circ} \mathrm{C}$; therefore, it seemed reasonable to pyrolyze samples just below this temperature for periods that would ensure complete decomposition but limit the amount of diffusion that might lead to phase transformations. Furthermore, most of the materials crystallize by $700^{\circ} \mathrm{C}$, so a pyrolysis temperature of $500^{\circ} \mathrm{C}$ was chosen to (1) look for the onset of crystallization and/or (2) characterize the amorphous material at higher temperatures. Thus, 1-2 g samples of the glycolato silicates were heated to selected temperatures $\left(10^{\circ} \mathrm{C} / \mathrm{min}\right.$ in air to $300^{\circ}, 500^{\circ}$, $700^{\circ}, 900^{\circ} \mathrm{C}$ followed by a 2 -h hold), and the DRIFT spectra and XRD patterns of the recovered products were recorded.

In general, the heated bulk samples first transform into amorphous materials that contain some carbonate $\left(\mathrm{CO}_{3}{ }^{2-}\right)$ and bicarbonate $\left(\mathrm{HCO}_{3}^{-}\right)$species (identified by DRIFTS). On further heating, the amorphous carbonate containing materials transform (with the exception of the potassium compound) into the line compounds $\mathrm{M}_{2} \mathrm{Si}_{2} \mathrm{O}_{5}$, as might be anticipated based on the initial $\mathrm{M}_{2} \mathrm{Si}_{2}\left(\mathrm{OCH}_{2} \mathrm{CH}_{2} \mathrm{O}\right)_{5}$ composition. The associated crystallization processes were followed by XRD, whereas DRIFT spectroscopy proved to be most useful in identifying the processes that occur in the formation of amorphous materials. The decomposition patterns of all four precursors are discussed below individually.

\section{(l) $\mathrm{Li}_{2} \mathrm{Si}_{2}\left(\mathrm{OCH}_{2} \mathrm{CH}_{2} \mathrm{O}\right)_{5}{ }^{4}$}

(A) Thermal Analyses: The TGA profile for the monomer (Fig. 1) shows a ceramic yield of $34.1 \%$, which is very close to the calculated value of $34.7 \%$ (see Table III). The TGA shows an initial weight loss of $14-15 \%$ at $180-240^{\circ} \mathrm{C}$. This process appears to correspond to dimerization of the monomer wherein one monodentate ethylene glycol ligand is lost for every two monomer units. The loss calculated for this process is $14 \%$. The dimer (Fig. 1) shows a ceramic yield of $40.4 \%$, which is quite close to the calculated value of $40.5 \%$ (Table III). The weight loss at $200-340^{\circ} \mathrm{C}$ corresponds to oxidative decomposition of the dimer to $\mathrm{Li}_{2} \mathrm{O} \cdot 2 \mathrm{SiO}_{2}$ (see below).

The DTA for the lithium dimer (Fig. 2) exhibits an exotherm at $\approx 365^{\circ} \mathrm{C}$ as a result of oxidation of the glycolato silicate ligands as confirmed by the TGA. The small exotherm at $\approx 565^{\circ} \mathrm{C}$ is most probably crystallization of lithium disilicate, as corroborated by the XRD (see below). The exotherm at $\approx 1025^{\circ} \mathrm{C}$ may result from oxidation of a small amount of residual carbon. ${ }^{14}$ The endotherm that follows the exotherm coincides with the melting point of $\mathrm{Li}_{2} \mathrm{O} \cdot 2 \mathrm{SiO}_{2}\left(1030^{\circ} \mathrm{C}\right)$.

Marotta et al. ${ }^{15}$ have estimated the maximum nucleation rate for $\mathrm{Li}_{2} \mathrm{O} \cdot 2 \mathrm{SiO}_{2}$ as a function of temperature and heating rate (by DTA), using as-quenched powder and bulk glass samples. They report that, in general, crystallization is shifted to higher temperatures using slower heating rates or bulk glass samples. For example, they find that bulk $\mathrm{Li}_{2} \mathrm{O} \cdot 2 \mathrm{SiO}_{2}$ crystallizes at $587^{\circ} \mathrm{C}$ when heated at $5^{\circ} \mathrm{C} / \mathrm{min}$. Our studies, with the finely divided powders produced from the precursor, show a crystallization temperature of $565^{\circ} \mathrm{C}$, for a ramp rate of $10^{\circ} \mathrm{C} / \mathrm{min}$. This temperature difference can be attributed to a higher heating rate and

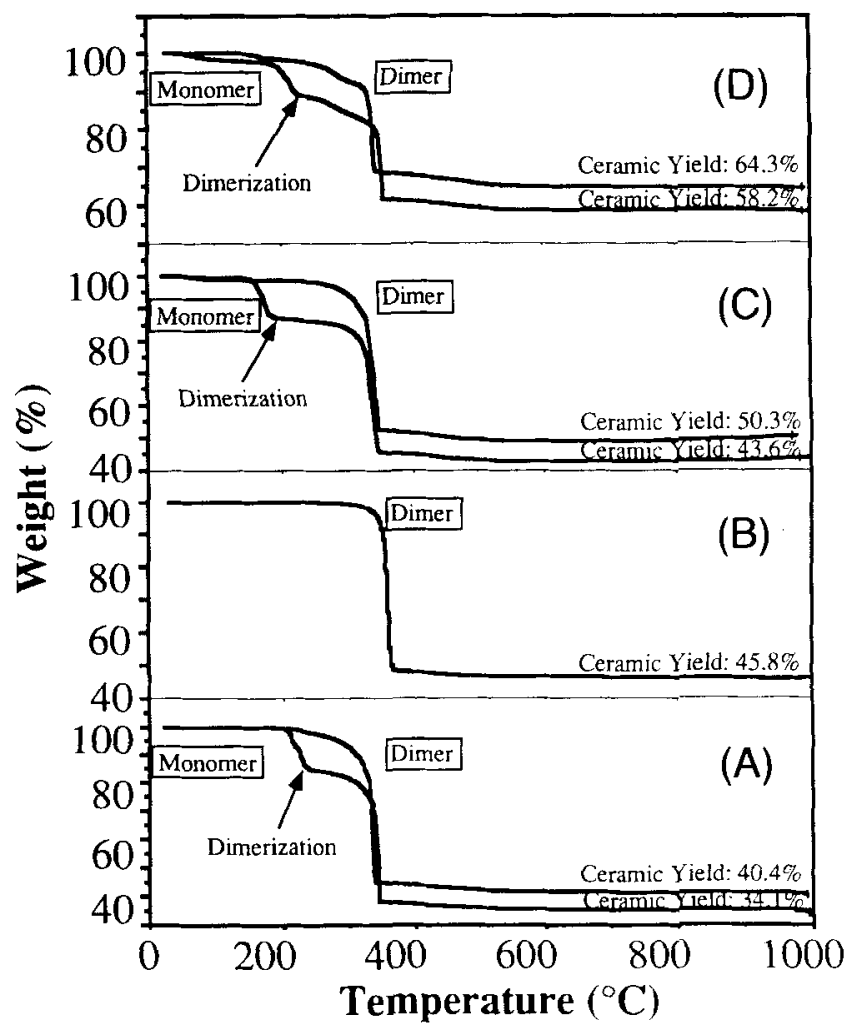

Fig. 1. TGA overlay for alkali silicate monomers and dimers; ramp was $10^{\circ} \mathrm{C} / \mathrm{min}$ in synthetic air: (A) lithium glycolato silicate, (B) sodium glycolato silicate, (C) potassium glycolato silicate, (D) cesium glycolato silicate.

Table III. Calculated and Experimental Ceramic Yields for the Monomer, $\mathrm{MSi}\left(\mathrm{OCH}_{2} \mathrm{CH}_{2} \mathrm{O}\right)_{2} \mathrm{OCH}_{2} \mathrm{CH}_{2} \mathrm{OH}$, and Dimer, $\mathrm{M}_{2} \mathrm{Si}_{2}\left(\mathrm{OCH}_{2} \mathrm{CH}_{2} \mathrm{O}\right)_{5}$, Where $\mathrm{M}=\mathrm{Li}, \mathrm{Na}, \mathrm{K}$, or $\mathrm{Cs}^{*}$

\begin{tabular}{llllll}
\hline \multirow{2}{*}{$\begin{array}{c}\text { M glycolato } \\
\text { silicate }\end{array}$} & \multicolumn{2}{c}{ Monomer $(\%)$} & & \multicolumn{2}{c}{ Dimer (\%) } \\
\cline { 2 - 3 } \cline { 5 - 6 } & Expt & Calc & & Expt & Calc \\
\hline Lithium & 34.1 & 34.7 & 40.4 & 40.5 \\
Sodium & & 39.2 & & 45.8 & 45.3 \\
Potassium & 43.4 & 43.2 & & 50.3 & 49.3 \\
Cesium & 58.2 & 58.6 & & 64.3 & 64.6 \\
\hline
\end{tabular}

*The calculated yields are based on assuming $0.5 \mathrm{M}_{2} \mathrm{Si}_{2} \mathrm{O}_{5}$ as the end product for the monomer and $\mathrm{M}_{2} \mathrm{Si}_{2} \mathrm{O}_{9}$ for the dimer. The experimental values are the TGA yields at $1000^{\circ} \mathrm{C}$.

smaller particle size. The smaller particle size implies higher surface areas, which in turn implies high surface energies which will drive crystallization and therefore lower crystallization temperatures.

(B) XRD: The XRD patterns displayed in Fig. 3 show phase development of lithium silicate on pyrolysis at selected temperatures. Initially, the monomeric and dimeric lithium glycolato silicates are crystalline as indicated by sharp peaks at $2 \theta \approx 12.5^{\circ}, 16.5^{\circ}, 20^{\circ}$ and $10^{\circ}, 11.5^{\circ}, 21^{\circ}$, etc., respectively. At $300^{\circ} \mathrm{C}$, the lithium silicate sample is X-ray amorphous. At $500^{\circ} \mathrm{C}$, the pattern indicates the onset of crystallization of monoclinic, orthorhombic dilithium disilicate, $\alpha-\mathrm{Li}_{2} \mathrm{Si}_{2} \mathrm{O}_{5}$, (JCPDS File 17-447), evidenced by a well-defined peak at $2 \theta \approx$ $25^{\circ}$ and smaller peaks at $2 \theta \approx 37.5^{\circ}, 31^{\circ}$, etc. The DTA crystallization temperature of $565^{\circ} \mathrm{C}$ differs from crystallization temperature $\left(500^{\circ} \mathrm{C}\right)$ indicated by XRD, because the XRD samples were held at temperature for $2 \mathrm{~h}$, making crystallization possible at a lower temperature. At higher temperatures $\alpha-\mathrm{Li}_{2} \mathrm{O}$. $2 \mathrm{SiO}_{2}$ continues to crystallize. In addition, small peaks indicative of traces of orthorhombic pseudohexagonal lithium metasilicate, $\mathrm{Li}_{2} \mathrm{O} \cdot \mathrm{SiO}_{2}$ (JCPDS File 29-829), begin to appear at $18.8^{\circ}, 27^{\circ}$, and $33^{\circ} 2 \theta$ at $700^{\circ} \mathrm{C}$. At $900^{\circ} \mathrm{C}$, the $\mathrm{Li}_{2} \mathrm{O} \cdot \mathrm{SiO}_{2}$ peaks 


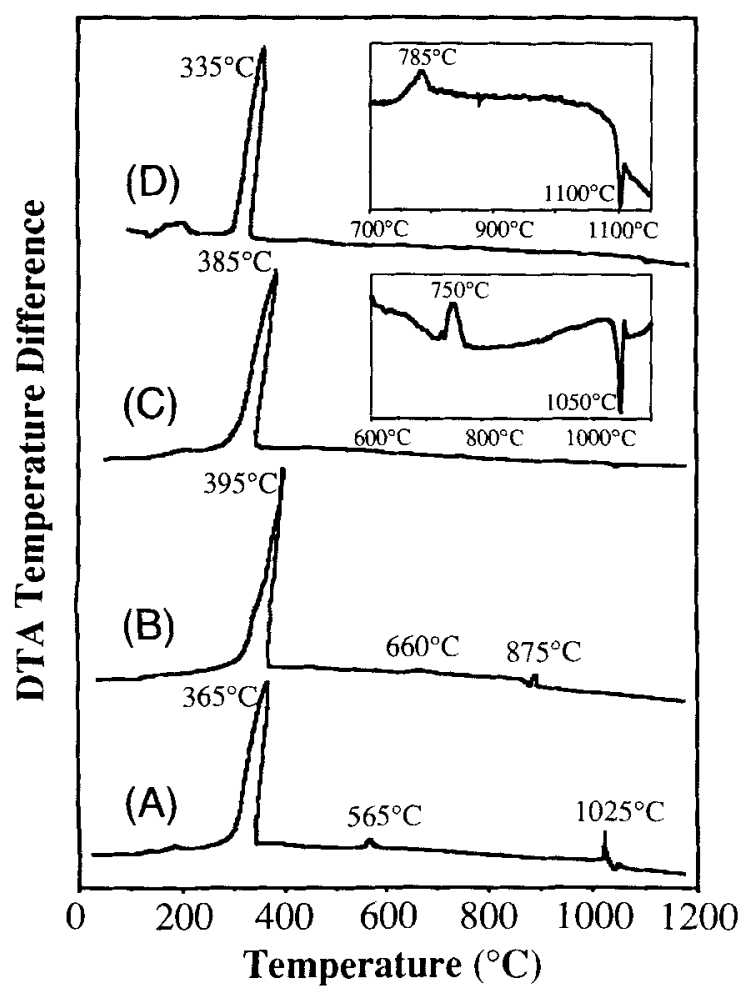

Fig. 2. DTA overlay of $\mathrm{M}_{2} \mathrm{Si}_{2}\left(\mathrm{OCH}_{2} \mathrm{CH}_{2} \mathrm{O}\right)_{5}$; ramp was $10^{\circ} \mathrm{C} / \mathrm{min}$ in synthetic air: (A) $\mathrm{Li}_{2} \mathrm{Si}_{2}\left(\mathrm{OCH}_{2} \mathrm{CH}_{2} \mathrm{O}\right)_{5}$, (B) $\mathrm{Na}_{2} \mathrm{Si}_{2}\left(\mathrm{OCH}_{2} \mathrm{CH}_{2} \mathrm{O}\right)_{5}$, (C) $\mathrm{K}_{2} \mathrm{Si}_{2}\left(\mathrm{OCH}_{2} \mathrm{CH}_{2} \mathrm{O}\right)_{5},(\mathrm{D}) \mathrm{Cs}_{2} \mathrm{Si}_{2}\left(\mathrm{OCH}_{2} \mathrm{CH}_{2} \mathrm{O}\right)_{5}$.

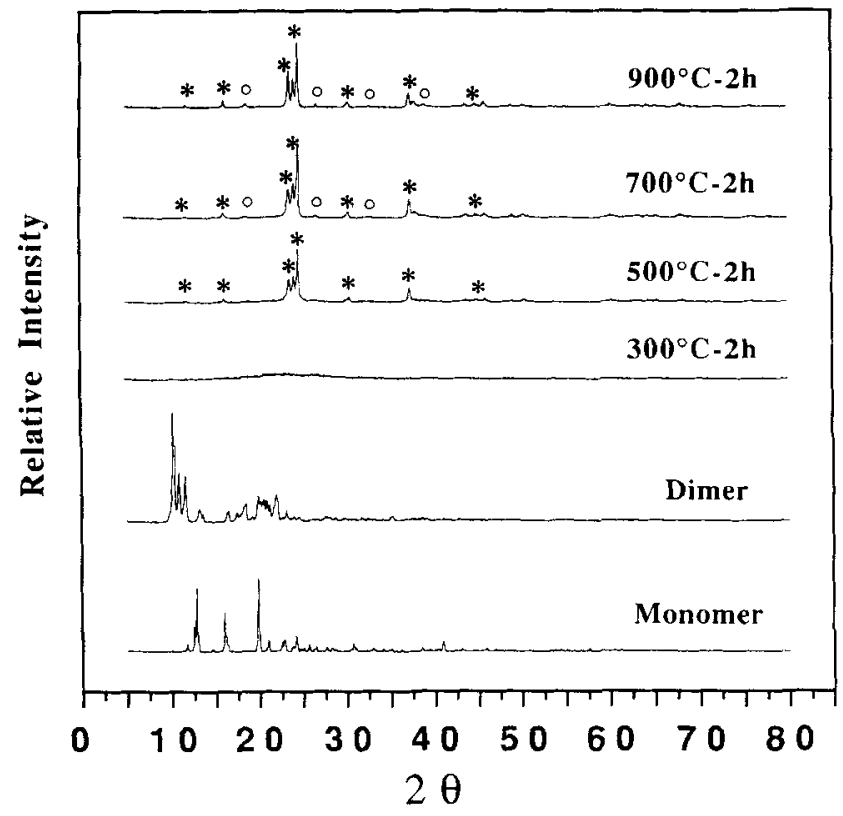

Fig. 3. XRDs of $\mathrm{Li}_{2} \mathrm{Si}_{2}\left(\mathrm{OCH}_{2} \mathrm{CH}_{2} \mathrm{O}\right)_{5}$ : (*) orthorhombic $\alpha-\mathrm{Li}_{2} \mathrm{Si}_{2} \mathrm{O}_{5}$, JCPDS File 17-447; (o) orthorhombic $\mathrm{Li}_{2} \mathrm{SiO}_{3}$, JCPDS File 29-829.

sharpen somewhat; however, the relative intensities (with respect to $\mathrm{Li}_{2} \mathrm{O} \cdot 2 \mathrm{SiO}_{2}$ ) do not change.

(C) DRIFTS: The DRIFT spectra are presented in Fig. 4. The monomer shows $v(\mathrm{OH})$ vibrations at $3250 \mathrm{~cm}^{-1}$ and $v(\mathrm{CH})$ vibrations at $2800-3000 \mathrm{~cm}^{-1}$. The dimerization process brought on by heating the monomer to $170^{\circ} \mathrm{C}$ in vacuo results in an FTIR spectrum devoid of $v(\mathrm{OH})$ vibrations but still retaining the $v(\mathrm{CH})$ vibrations. The peaks in the region of $1050-1140$ $\mathrm{cm}^{-1}$ correspond to a combination of $v(\mathrm{SiO})$ and $v(\mathrm{CO})$ vibrations. The narrow, sharp peaks in the spectra of the monomer

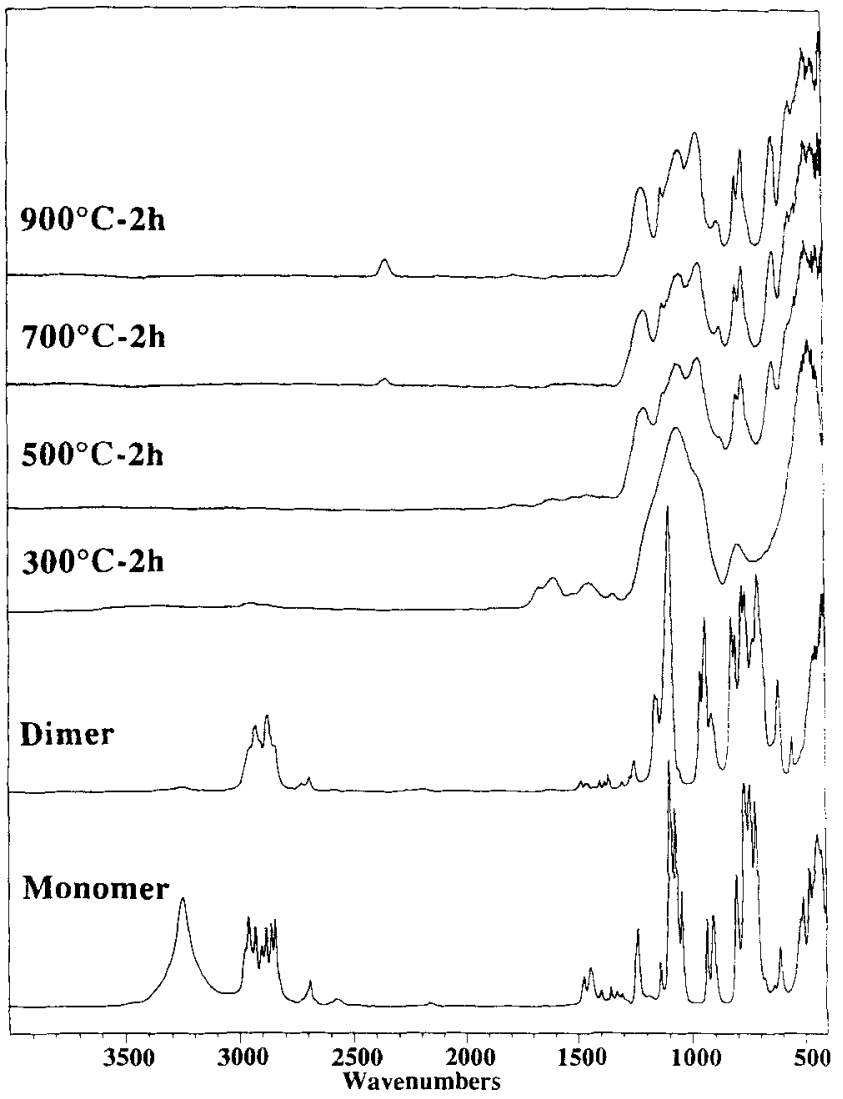

Fig. 4. DRIFTS of $\mathrm{Li}_{2} \mathrm{Si}_{2}\left(\mathrm{OCH}_{2} \mathrm{CH}_{2} \mathrm{O}\right)_{5}$.

and dimer attest to their crystallinity as corroborated by the XRD. The high order found in crystalline materials limits the number of vibrational modes available to each bond in the individual molecule. In contrast, there are a wider number of physical environments possible in amorphous materials; hence a given vibration mode will be an envelope that reflects the variations in the physical environment. Thus, specific vibrational modes, e.g., $v(\mathrm{SiO})$, will be broader in an amorphous material.

The broad peaks found in the $300^{\circ} \mathrm{C}$ spectrum are characteristic of an amorphous material. The band at $1430 \mathrm{~cm}^{-1}$ is due to the formation of amorphous (since it is not seen by XRD) $\mathrm{Li}_{2} \mathrm{CO}_{3}$, corroborated by running a spectrum of an authentic sample and by the literature. ${ }^{16}$ The carbonate peak intensities are relatively small, ${ }^{16}$ indicating that they represent only a minor phase. The small peaks at 1330,1600 and $1660 \mathrm{~cm}^{-1}$ match the bicarbonate absorption spectra published for $\mathrm{Na}, \mathrm{K}$, and $\mathrm{Cs}$ bicarbonates and for peaks found during study of the $\mathrm{Na}$, $\mathrm{K}$, and $\mathrm{Cs}$ pyrolysis products. ${ }^{16 a}$ The literature suggests that lithium bicarbonate is stable only in solution; ${ }^{16 \mathrm{~b} . c}$ however, one report describes its isolation by precipitation with alcohol at $30^{\circ} \mathrm{C}$, but with limited characterization..$^{16 c . d}$ Thus, assignment of these peaks as $\mathrm{LiHCO}_{3}$ must be considered tentative. Furthermore, because all of the IR samples were pyrolyzed above the decomposition temperatures of the bicarbonates $\left(\mathrm{NaHCO}_{3}\right.$ : $50^{\circ} \mathrm{C} ; \mathrm{KHCO}_{3}: 190^{\circ} \mathrm{C}$ ), ${ }^{17}$ it is most likely that the bicarbonate species are not a product of pyrolysis but result from exposure to atmosphere. Although care was taken not to expose the samples to the atmosphere, it is possible that the IR samples adsorbed some moisture during sample transfer from the dry box to the IR sample chamber, resulting in the formation of bicarbonates by reaction of moisture with the carbonates. DRIFT spectroscopy records spectra by reflectance from the sample surface, so even small amounts of bicarbonates formed at the surface can be detected by IR.

The spectra at $500^{\circ}, 700^{\circ}$, and $900^{\circ} \mathrm{C}$ are free of the carbonate and bicarbonate peaks seen in the $300^{\circ} \mathrm{C}$ spectrum and indicate 
coincidentally that the materials formed at these temperatures are crystalline, as evidenced by sharp peaks at $<1100 \mathrm{~cm}$ ', in the fingerprint region. The $1050 \mathrm{~cm}^{-1}$ band is assigned to an asymmetric $v(\mathrm{Si}-\mathrm{O}-\mathrm{Si})$ peak and the band at $\approx 960 \mathrm{~cm}^{-1}$ to $v(\mathrm{Si}-\mathrm{O})$ of the nonbridging species $\left(\mathrm{Si}-\mathrm{O}^{-} \mathrm{Li}^{+}\right)$, by analogy with spectra reported for Si-O ${ }^{-} \mathrm{Na}^{+}$(Refs. 18-20) and Raman spectra for alkali silicates. ${ }^{21}$ The peaks at $\approx 760$ and $790 \mathrm{~cm}^{-1}$ may arise because of contributions from $v(\mathrm{Si}-\mathrm{O}-\mathrm{Si})$ symmetric vibrations. The DRIFT spectra correlate well with the XRD patterns. Both show an amorphous phase at $300^{\circ} \mathrm{C}$ and crystalline phases at higher temperatures.

Recent studies of the lithium silicate system by Klein et al. ${ }^{22}$ and Loehman et al. ${ }^{23}$ provide a useful comparison to our work. Klein et al. studied the effects of heat treatments on polymerized and infiltrated lithium silicate gels. The crystallization temperature differed from system to system ranging from $200^{\circ}$ to $800^{\circ} \mathrm{C}$; however, in all instances the first silicate detected by XRD was $\mathrm{Li}_{2} \mathrm{O} \cdot \mathrm{SiO}_{2}$ rather than $\mathrm{Li}_{2} \mathrm{O} \cdot 2 \mathrm{SiO}_{2}$. At higher temperatures, the $\mathrm{Li}_{2} \mathrm{O} \cdot 2 \mathrm{SiO}_{2}$ phase appeared at the expense of the initially formed $\mathrm{Li}_{2} \mathrm{O} \cdot \mathrm{SiO}_{2}$. This contrasts with our system, where the first crystalline phase is $\mathrm{Li}_{2} \mathrm{O} \cdot 2 \mathrm{SiO}_{2}$, which appears at $500^{\circ} \mathrm{C}$, and only small and constant amounts of $\mathrm{Li}_{2} \mathrm{O} \cdot \mathrm{SiO}_{2}$ appear at $700^{\circ} \mathrm{C}$ and above.

Loehman et al. studied the crystallization of a lithium silicate glass ceramic nucleated by $\mathrm{Li}_{3} \mathrm{PO}_{4}$. These authors found that $\mathrm{Li}_{2} \mathrm{O} \cdot \mathrm{SiO}_{2}$ appeared around $650^{\circ} \mathrm{C}$ as the first crystalline phase and then disappeared, converting to $\mathrm{Li}_{2} \mathrm{O} \cdot 2 \mathrm{SiO}_{2}$ at $850^{\circ} \mathrm{C}$. According to their DSC and DTA results, the activation energy for formation of $\mathrm{Li}_{2} \mathrm{O} \cdot \mathrm{SiO}_{2}$ is at least $90 \mathrm{~kJ} / \mathrm{mol}$ more negative than that for $\mathrm{Li}_{2} \mathrm{Si}_{2} \mathrm{O}_{5}$, which may explain the preferential formation of $\mathrm{Li}_{2} \mathrm{O} \cdot \mathrm{SiO}$ in their system. These results are similar to those of Klein et al. and again contrast with our own observations.

Because the three systems vary in preparation, it is difficult to offer an explanation for the observed differences. It is probable that atomic mixing and exactly preserved stoichiometry in the end products, in our system, allow for the direct formation of lithium disilicate with minimal segregation. In keeping with this conclusion, the appearance of small amounts of $\mathrm{Li}_{2} \mathrm{O} \cdot \mathrm{SiO}_{2}$ in our system may result from the small amounts of $\mathrm{Li}_{2} \mathrm{CO}_{3}$ formed, as identified by IR. The formation and segregation of the carbonate could be responsible for the formation of $\mathrm{Li}_{2} \mathrm{O}$. $\mathrm{SiO}_{2}$ at higher temperatures where the carbonate disappears.

\section{(2) $\mathrm{Na}_{2} \mathrm{Si}_{2}\left(\mathrm{OCH}_{2} \mathrm{CH}_{2} \mathrm{O}\right)_{5}$}

Unlike the other alkali glycolato derivatives, which precipitate out as monomer, the sodium silicate precursor is isolated only as the dimer as seen in the TGA (Fig. 1). The monomer has recently been isolated and its crystal structure obtained. ${ }^{24}$

(A) Thermal Analyses: The found TGA ceramic yield for the sodium silicate dimer is $45.8 \%$ against a calculated value of $45.3 \%$ (Table III). The TGA profile (Fig. 1) is similar to that of lithium silicate dimer, indicating a weight loss at $310-365^{\circ} \mathrm{C}$ due to oxidative decomposition of the dimer to amorphous $\mathrm{Na}_{2} \mathrm{O} \cdot 2 \mathrm{SiO}_{2}$ (see XRD, Fig. 5). The large exotherm seen in the DTA (Fig. 2) at $395^{\circ} \mathrm{C}$ corroborates this weight loss. A small exotherm at $660^{\circ} \mathrm{C}$ is likely due to crystallization of $\alpha-\mathrm{Na}_{2} \mathrm{O}$. $2 \mathrm{SiO}_{2}$ (see XRD, Fig. 5). An endotherm at $\approx 875^{\circ} \mathrm{C}$ corresponds to the $T_{\text {m }}$ of $\mathrm{Na}_{2} \mathrm{Si}_{2} \mathrm{O}_{5}$ at $\approx 874^{\circ} \mathrm{C}$. The exotherm following the endotherm at $875^{\circ} \mathrm{C}$ may result from oxidation of a small amount of trapped, residual carbon released as the material melts. Note that in both the $\mathrm{Li}$ and Na DTA samples the ceramic yields are, within experimental error, identical to the calculated values; thus, the amount of residual carbon must fall in the range of the experimental error, which is about $0.3-0.5 \mathrm{wt} \%$.

(B) XRD: As seen in Fig. 5, which displays XRD patterns at selected pyrolysis temperatures, the dimer is crystalline as evidenced by two sharp peaks at $2 \theta \approx 11^{\circ}$ and $18^{\circ}$. The sample is amorphous following pyrolysis to $300^{\circ}$ and $500^{\circ} \mathrm{C}$. By $700^{\circ} \mathrm{C}$, the sample has crystallized to orthorhombic disodium disilicate, $\alpha-\mathrm{Na}_{2} \mathrm{Si}_{2} \mathrm{O}_{5}$ (JCPDS File 22-1397), as indicated by sharp peaks. ${ }^{25}$ This result is in accord with the DTA crystallization

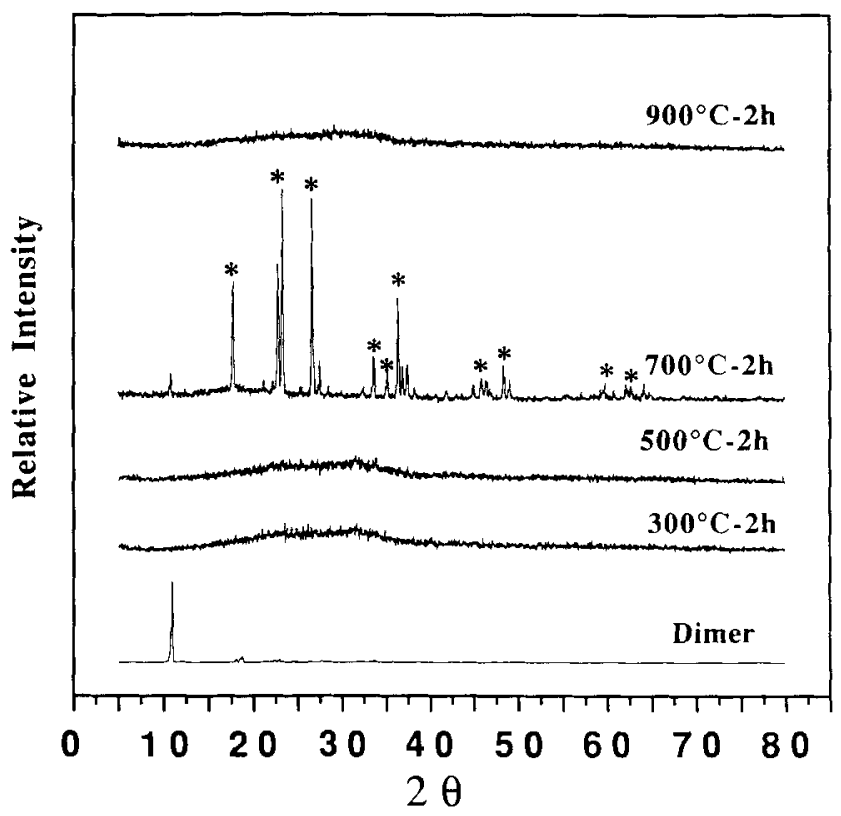

Fig. 5. XRDs of $\mathrm{Na}_{2} \mathrm{Si}_{2}\left(\mathrm{OCH}_{2} \mathrm{CH}_{2} \mathrm{O}\right)_{5}:(*)$ orthorhombic $\alpha-\mathrm{Na}_{2} \mathrm{Si}_{2} \mathrm{O}_{5}$, JCPDS File 22-1397.

exotherm observed at $660^{\circ} \mathrm{C}$. The lack of a powder pattern in the $900^{\circ} \mathrm{C} \mathrm{XRD,} \mathrm{suggesting} \mathrm{a} \mathrm{glassy} \mathrm{phase,} \mathrm{is} \mathrm{also} \mathrm{expected}$ given the DTA data and the known $T_{\mathrm{m}}$ of $\mathrm{Na}_{2} \mathrm{Si}_{2} \mathrm{O}_{5}$.

(C) DRIFTS: DRIFT spectra are shown in Fig. 6 and are quite similar to those seen for the $\mathrm{Li}$ dimer. The absence of peaks in the $v(\mathrm{O}-\mathrm{H})$ region $\left(3200-3300 \mathrm{~cm}{ }^{\prime}\right)$ confirms the direct formation of the dimer without contamination of the monomer. The crystalline dimer exhibits $v(\mathrm{C}-\mathrm{H})$ vibrations at $2800-3000 \mathrm{~cm}^{-1}$. The peak at $\approx 1090 \mathrm{~cm}^{-1}$ corresponds to a combination of $v(\mathrm{Si}-\mathrm{O})$ and $v(\mathrm{C}-\mathrm{O})$ asymmetric vibrations.

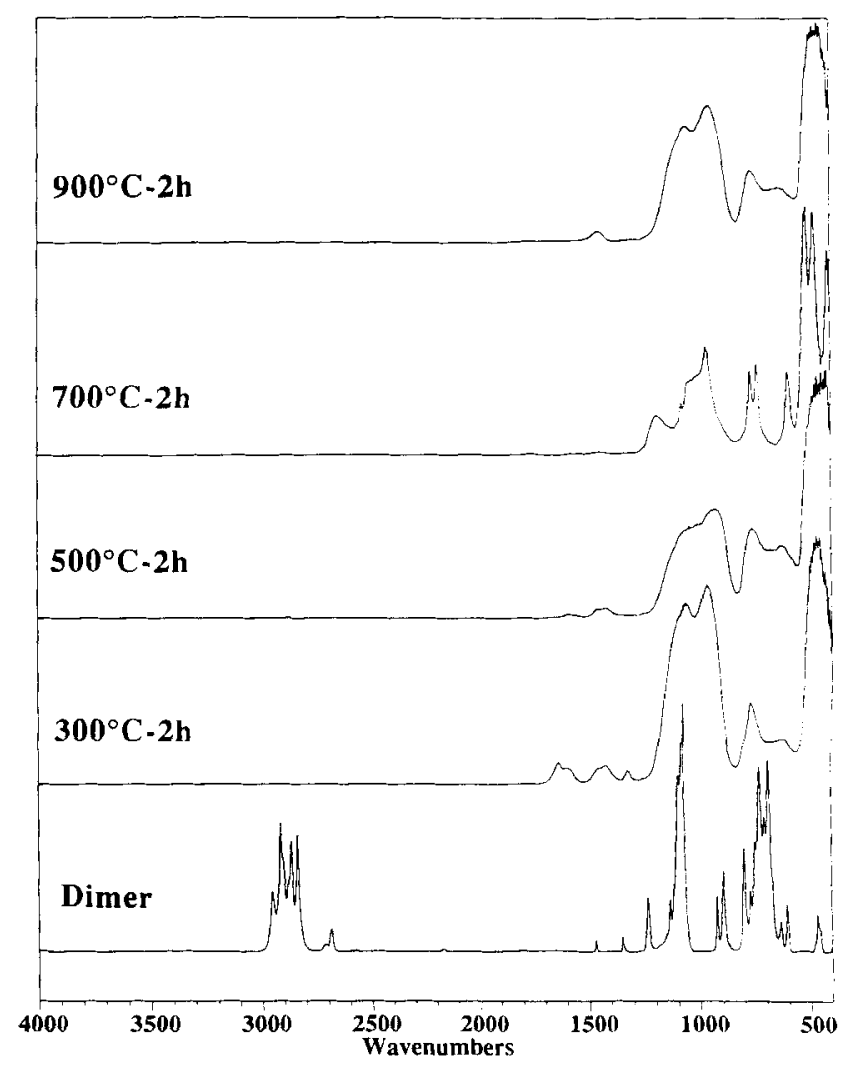

Fig. 6. DRIFTS of $\mathrm{Na}_{2} \mathrm{Si}_{2}\left(\mathrm{OCH}_{2} \mathrm{CH}_{2} \mathrm{O}\right)_{5}$. 
The broad bands in the $300^{\circ}$ and $500^{\circ} \mathrm{C}$ samples confirm the amorphous nature of these intermediates as seen in the XRD. Like the Li intermediate pyrolyses products, carbonate and bicarbonate bands are observed. The band at $1430 \mathrm{~cm}^{-1}$ is attributed to small amounts of $\mathrm{Na}_{2} \mathrm{CO}_{3}$, as corroborated by the spectrum of an authentic sample. ${ }^{16}$ The small peaks at 1330 , 1600 , and $1650 \mathrm{~cm}^{-1}$ are due to formation of $\mathrm{NaHCO}_{3}$, as discussed above. ${ }^{17}$ The $\mathrm{NaHCO}_{3}$ bands disappear at $500^{\circ} \mathrm{C}$; however, unlike the lithium studies, the carbonate bands remain and disappear only at $700^{\circ} \mathrm{C} .^{23}$

The melting temperature for pure $\mathrm{Na}_{2} \mathrm{CO}_{3}$ is $851^{\circ} \mathrm{C}$ (vs $730^{\circ} \mathrm{C}$ for $\mathrm{Li}_{2} \mathrm{CO}_{3}$ ); thus, its decomposition to $\mathrm{Na}_{2} \mathrm{O}$ and $\mathrm{CO}_{2}$ at $700^{\circ} \mathrm{C}$ $\left(>0.8 T_{n 1}\right)$ might be expected because of the $2-\mathrm{h}$ hold, especially if it is driven by coincidental formation of $\alpha-\mathrm{Na}_{2} \mathrm{Si}_{2} \mathrm{O}_{5}$. This also provides an explanation for the decomposition of $\mathrm{Li}_{2} \mathrm{CO}_{3}$ at $500^{\circ} \mathrm{C}$ following a $2-\mathrm{h}$ hold.

Many of the peaks in the $700^{\circ} \mathrm{C}$ spectrum sharpen as $\alpha-\mathrm{Na}_{2} \mathrm{Si}_{2} \mathrm{O}_{5}$ crystallizes (see Fig. 5). The band at $\approx 980 \mathrm{~cm}^{-1}$ is assigned to the stretching mode of the $\mathrm{Si}-\mathrm{O}$ bond in $\mathrm{Si}-\mathrm{O}^{-} \mathrm{Na}^{+}{ }^{18-21}$ The peaks at $\approx 750$ and $780 \mathrm{~cm}^{-1}$ correspond to $v(\mathrm{Si}-\mathrm{O}-\mathrm{Si})$ vibrations due to symmetric stretching. Peaks at $\approx 490$ and $530 \mathrm{~cm}^{-1}$ are attributed to $\mathrm{Si}-\mathrm{O}-\mathrm{Si}$ bending motions [ $\delta(\mathrm{Si}-\mathrm{O}-\mathrm{Si})]$. The broad bands in the $900^{\circ} \mathrm{C}$ spectrum are consistent with a glassy phase. These data correlate very well with XRD and thermal analysis results.

\section{(3) $\mathrm{K}_{2} \mathrm{Si}_{2}\left(\mathrm{OCH}_{2} \mathrm{CH}_{2} \mathrm{O}\right)_{5}{ }^{\prime}$}

(A) Thermal Analyses: The found TGA ceramic yield for the monomer is $43.4 \%$ is, within experimental error, identical to the calculated value of $43.2 \%$ (Table III). The TGA profile (Fig. 1) for potassium glycolato silicate is consistent with that observed for the lithium analogue. The $13-14 \%$ weight loss at $150-200^{\circ} \mathrm{C}$ corresponds to that expected (calculated) for dimerization $(13 \%)$. The dimer ceramic yield of $50.3 \%$ is slightly higher than the calculated value of $49.3 \%$ (Table III). The weight loss at $250^{\circ}-350^{\circ} \mathrm{C}$ corresponds to the oxidative decomposition of dimer. The DTA (Fig. 2) indicates a large exotherm at $\approx 385^{\circ} \mathrm{C}$ due to oxidation reactions as seen for the $\mathrm{Li}$ and $\mathrm{Na}$ glycolato silicates. The exotherm at $750^{\circ} \mathrm{C}$ (see inset) is due to crystallization (see XRD, Fig. 7). The small endotherm at $\approx 1050^{\circ} \mathrm{C}$ (see inset) most likely results from melting $\left(T_{\mathrm{m}}\right.$ of $\mathrm{K}_{2} \mathrm{Si}_{2} \mathrm{O}_{5}$ is $1015 \pm 10^{\circ} \mathrm{C}$ ).

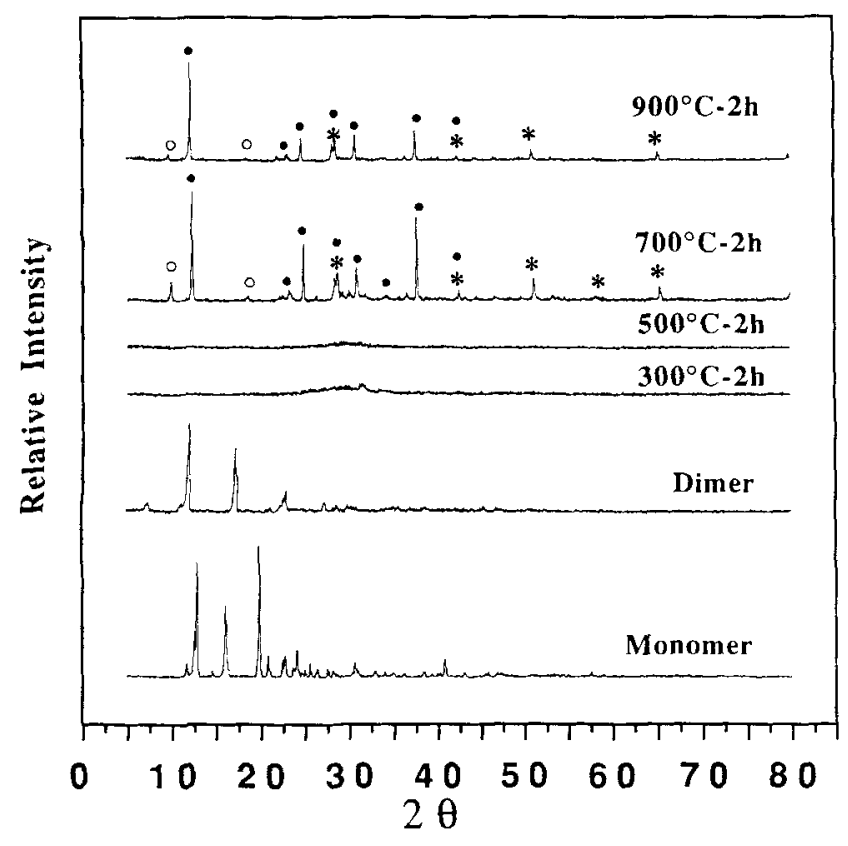

Fig. 7. XRDs of $\mathrm{K}_{2} \mathrm{Si}_{2}\left(\mathrm{OCH}_{2} \mathrm{CH}_{2} \mathrm{O}\right)_{5}$ : (0) orthorhombic $\mathrm{K}_{2} \mathrm{Si}_{2} \mathrm{O}_{5}$, JCPDS File 26-1331; $\left(^{*}\right)$ hexagonal $\mathrm{K}_{2} \mathrm{Si}_{4} \mathrm{O}_{4}$, JCPDS File 30-978; (•) hexagonal $\alpha-\mathrm{K}_{2} \mathrm{O}$, JCPDS File 26-1327.
(B) XRD: Figure 7 shows the XRD patterns at selected temperatures. Like the $\mathrm{Li}$ analogue, the monomer and dimer are crystalline as shown by sharp peaks at $2 \theta \approx 13^{\circ}, 16^{\circ}, 20^{\circ}$ and $12^{\circ}, 17.5^{\circ}, 23^{\circ}$, etc., respectively. The diffraction patterns at $300^{\circ}$ and $500^{\circ} \mathrm{C}$ indicate that the material is mostly amorphous. At $700^{\circ} \mathrm{C}$, the sample crystallizes to monoclinic, pseudo-orthorhombic, $\mathrm{K}_{2} \mathrm{Si}_{2} \mathrm{O}_{5}$ (JCPDS File 26-1331), hexagonal $\alpha-\mathrm{K}_{2} \mathrm{O}$ (JCPDS File 26-1327), and hexagonal $\mathrm{K}_{2} \mathrm{Si}_{4} \mathrm{O}_{9}$ (JCPDS File $30-$ 978) as indicated by sharp peaks. The observation of three phases simultaneously limits our ability to interpret the DTA data, other than to say that the observation of crystalline phases at $700^{\circ} \mathrm{C}$, after a 2 -h hold, is in keeping with the DTA crystallization temperature of $750^{\circ} \mathrm{C}$ (see discussion of lithium glycolato silicate DTA studies).

Unlike the other precursors, crystallization continues on heating to $900^{\circ} \mathrm{C}$, with the relative proportion of $\alpha-\mathrm{K}_{2} \mathrm{O}$ increasing. The segregation observed is at least partially a result of the formation of $\mathrm{K}_{2} \mathrm{CO}_{3}$ (see below). It may also be a consequence of the higher melting temperature (stability) of $\mathrm{K}_{2} \mathrm{CO}_{3}$ $\left(\mathrm{mp} 891^{\circ} \mathrm{C}\right.$ ) and the apparent absence of $\mathrm{KHCO}_{3}$. The difficulty in crystallizing $\mathrm{K}_{2} \mathrm{Si}_{2} \mathrm{O}_{5}$ even from stoichiometric melts is well known, ${ }^{3}$ as this system is especially susceptible to phase segregation due to a miscibility gap that leads to formation of potassium-rich and potassium-poor phases.

Because the information provided by the XRD and DRIFT spectra was not particularly definitive, we have sought to examine the pyrolyzed samples by ${ }^{29} \mathrm{Si}$ solid-state NMR. The results of this work will be presented in detail elsewhere; ${ }^{26}$ however, the pertinent findings are as follows. The primary chemical shift observed for the local silicon environments in the crystalline phases was $-93 \mathrm{ppm}\left(\mathrm{Q}_{3}\right)$, which corresponds to $\mathrm{K}_{2} \mathrm{Si}_{2} \mathrm{O}_{5}{ }^{27}$ and a minor peak at $-97 \mathrm{ppm}$ corresponding to $\mathrm{K}_{2} \mathrm{Si}_{4} \mathrm{O}_{9}{ }^{28}$ Because solid-state NMR permits a more quantitative evaluation of the components in the solid, these results suggest that the primary pyrolysis product is actually the anticipated product, $\mathrm{K}_{2} \mathrm{Si}_{2} \mathrm{O}_{5}$. The strong $\mathrm{K}_{2} \mathrm{O}$ peaks seen in the XRD therefore require some explanation. At this time, the only reasonable explanations that can be offered are that formation of amorphous $\mathrm{K}_{2} \mathrm{CO}_{3}$ occurs coincident with segregation and, on decomposition, a few large $\mathrm{K}_{2} \mathrm{O}$ grains grow, or $\mathrm{K}_{2} \mathrm{O}$ grains crystallize with a preferred orientation (hence sharper peaks in preferred directions) perhaps as a result of seeding by the smaller $\mathrm{K}_{2} \mathrm{Si}_{2} \mathrm{O}_{5}$ grains.

(C) DRIFTS: Figure 8 shows the DRIFT spectra for the potassium glycolato silicate pyrolyzed at selected temperatures. Like the $\mathrm{Li}$ precursor, the monomer shows $\mathrm{v}(\mathrm{O}-\mathrm{H})$ vibrations at $3250 \mathrm{~cm}^{-1}$ and $v(\mathrm{C}-\mathrm{H})$ vibrations at $2800-3000 \mathrm{~cm}^{-1}$ and the dimer only exhibits peaks corresponding to $v(\mathrm{C}-\mathrm{H})$. The peak at $\approx 1090 \mathrm{~cm}^{-1}$ again corresponds to both $v(\mathrm{Si}-\mathrm{O})$ and $v(\mathrm{C}-\mathrm{O})$ vibrations. The spectra at $300^{\circ}$ and $500^{\circ} \mathrm{C}$ are very similar and consist of broad absorption features indicative of amorphous materials. In the $300^{\circ} \mathrm{C}$ spectrum, the peaks at 1400 and 1460 $\mathrm{cm}^{-1}$ correspond to the formation of $\mathrm{K}_{2} \mathrm{CO}_{3}$. These peaks are relatively strong compared with the $\mathrm{CO}_{3}{ }^{2-}$ peaks observed in the $\mathrm{Li}, \mathrm{Na}$, and $\mathrm{Cs}$ (see below) spectra. This suggests that by comparison with the other metals, the affinity of the intermediate material for the $\mathrm{CO}_{2}$ produced during oxidative decomposition of the glycol ligands is much higher than for the other materials. This affinity is at least partly responsible for the degree of segregation observed. The very weak bands at 1580 and $1670 \mathrm{~cm}^{-1}$ may or may not correspond to $\mathrm{KHCO}_{3}$, as discussed above. ${ }^{17}$ At $500^{\circ} \mathrm{C}$ the carbonate peaks are still evident and even at $700^{\circ} \mathrm{C}$ some carbonate appears to remain present.

At $700^{\circ}$ and $900^{\circ} \mathrm{C}$, all the vibrational modes begin to sharpen, although not to the degree seen in the other spectral studies. This sharpening is indicative of crystallization and corroborates the XRD data. Some similarities with the other spectra include a band at $\approx 970 \mathrm{~cm}^{-1}$ likely due to $v\left(\mathrm{Si}-\mathrm{O}^{-} \mathrm{K}^{+}\right)$. Additional bands at $\approx 680-700$ and $760 \mathrm{~cm}^{-1}$ can be attributed to symmetric $v(\mathrm{Si}-\mathrm{O}-\mathrm{Si})$ vibrations. 


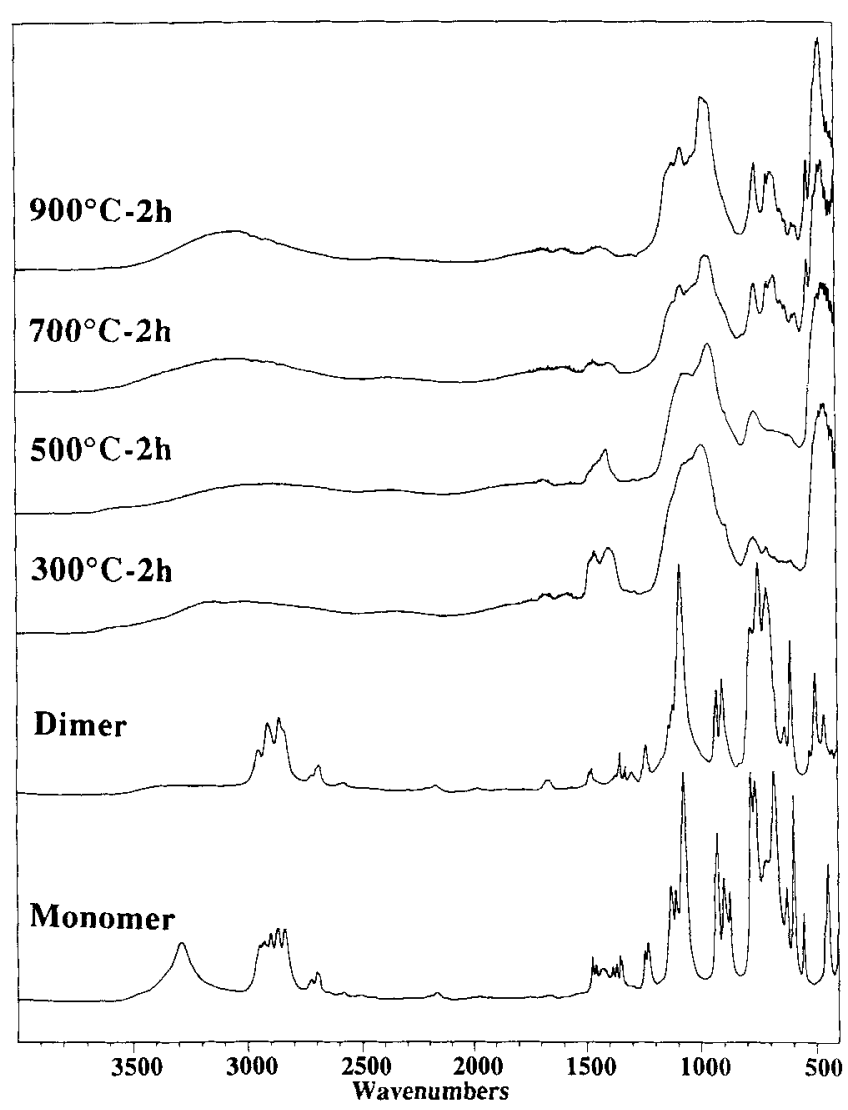

Fig. 8. DRIFTS of $\mathrm{K}_{2} \mathrm{Si}_{2}\left(\mathrm{OCH}_{2} \mathrm{CH}_{2} \mathrm{O}\right)_{5}$.

\section{(4) $\mathrm{Cs}_{2} \mathrm{Si}_{2}\left(\mathrm{OCH}_{2} \mathrm{CH}_{2} \mathrm{O}\right)_{5}{ }^{\mathrm{I}}$}

(A) Thermal Analyses: The TGA found ceramic yield for cesium silicate monomer is $58.2 \%$, which is very close to the calculated value of $58.6 \%$ (see Table III). The TGA profile (Fig. 1) is again similar to that seen for other glycolato silicates. The weight loss at $100-230^{\circ} \mathrm{C}$ corresponds to dimerization of the monomer (10-11\% found vs $10 \%$ calculated). The TGA for the dimer gives a ceramic yield of $64.3 \%$ which is, within experimental error, the same as the calculated value of $64.6 \%$ (Table III). The weight loss at $290-340^{\circ} \mathrm{C}$ corresponds to the oxidative decomposition of the precursor to amorphous $\mathrm{Cs}_{2} \mathrm{O}$. $2 \mathrm{SiO}_{2}$ (see XRD, Fig. 9). The DTA (Fig. 2) exhibits a large exotherm at $\approx 335^{\circ} \mathrm{C}$ corresponding to oxidation of the glycolato ligands. The small exotherm (see inset) at $\approx 785^{\circ} \mathrm{C}$ is likely the result of crystallization to $\mathrm{Cs}_{2} \mathrm{O} \cdot 2 \mathrm{SiO}_{2}$ (see XRD below). The small endotherm (see inset) at $1100^{\circ} \mathrm{C}$ may result from melting.

(B) XRD: Figure 9 shows XRD patterns for samples of the cesium glycolato silicate pyrolyzed to selected temperatures. Like the other glycolates, the monomer and dimer are crystalline, as shown by sharp peaks at $2 \theta \approx 8.5^{\circ}, 15^{\circ}, 24^{\circ}$ and $8.5^{\circ}, 23^{\circ}, 26^{\circ}$, etc., respectively. The $300^{\circ} \mathrm{C}$ sample shows some signs of crystallization; although, the intensities are too weak to permit characterization. At $500^{\circ} \mathrm{C}$, the pattern indicates the onset of crystallization of $\mathrm{Cs}_{2} \mathrm{Si}_{2} \mathrm{O}_{5}$, evidenced by a small peak at $2 \theta \approx 25^{\circ}$. The peaks become more defined and sharpen at $700^{\circ}$ and $900^{\circ} \mathrm{C}$, indicating crystallization of $\mathrm{Cs}_{2} \mathrm{Si}_{2} \mathrm{O}_{5}$ (JCPDS File 28-336). Unlike the potassium precursor, the cesium precursor forms only phase pure disilicate as also seen for the sodium precursor.

(C) DRIFTS: DRIFT spectra of pyrolyzed dimer are shown in Fig. 10. As above, a $v(\mathrm{O}-\mathrm{H})$ vibration is found at 3250 $\mathrm{cm}^{-1}$ and $v(\mathrm{C}-\mathrm{H})$ vibrations at $2800-3000 \mathrm{~cm}^{-1}$, whereas the dimer displays only $v(\mathrm{C}-\mathrm{H})$ vibrations in the same region. The peak at $\approx 1090 \mathrm{~cm}^{-1}$ corresponds to both $v(\mathrm{Si}-\mathrm{O})$ and $v(\mathrm{C}-\mathrm{O})$

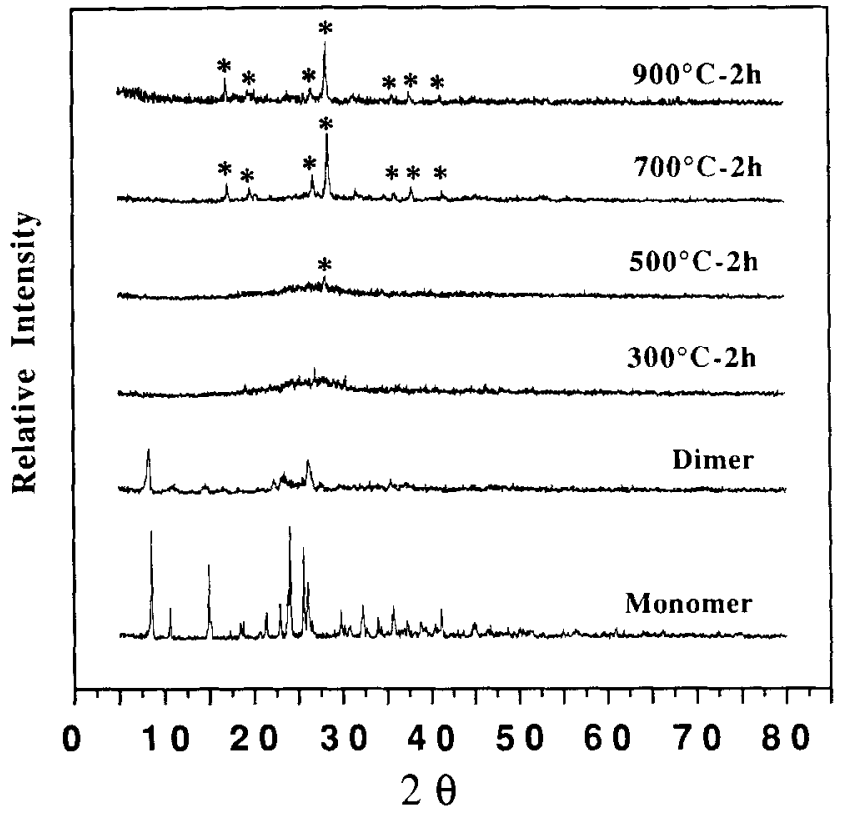

Fig. 9. XRDs of $\mathrm{Cs}_{2} \mathrm{Si}_{2}\left(\mathrm{OCH}_{2} \mathrm{CH}_{2} \mathrm{O}\right)_{5}:\left(^{*}\right) \mathrm{Cs}_{2} \mathrm{Si}_{2} \mathrm{O}_{5}$, JCPDS File 28336

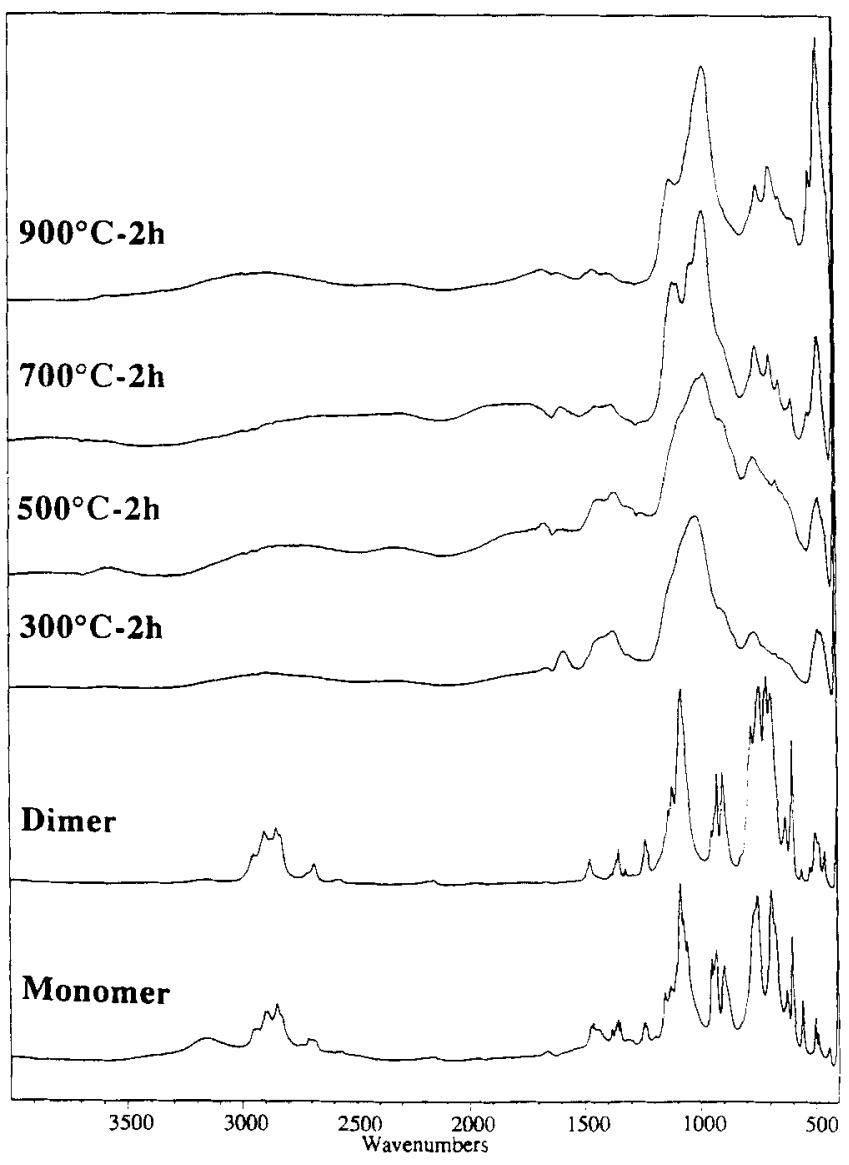

Fig. 10. DRIFTS of $\mathrm{Cs}_{2} \mathrm{Si}_{2}\left(\mathrm{OCH}_{2} \mathrm{CH}_{2} \mathrm{O}\right)_{5}$.

vibrations. The spectrum at $300^{\circ} \mathrm{C}$ is, as seen above, representative of an amorphous material. The bands at 1370 and 1460 $\mathrm{cm}^{-1}$, in the carbonate region, indicate the formation of $\mathrm{Cs}_{2} \mathrm{CO}_{3}$. The small peaks at 1600 and $1670 \mathrm{~cm}^{-1}$ are likely due to $\mathrm{CsHCO}_{3}$, as discussed above. ${ }^{17}$ The carbonate bands persist to $500^{\circ} \mathrm{C}$ and then are not found in the $700^{\circ} \mathrm{C}$ spectrum. This is 
likely a consequence of $\mathrm{Cs}_{2} \mathrm{CO}_{3}$ melting $\left(T_{\mathrm{m}}=610^{\circ} \mathrm{C}\right)$ which occurs coincident with decomposition/reaction. The fact that no apparent segregation is observed, despite the presence of reasonable amounts of carbonate, suggests that the argument made above for the importance of $\mathrm{K}_{2} \mathrm{CO}_{3}$ in segregation in the potassium system may not tell the whole story.

At $300^{\circ}$ and $500^{\circ} \mathrm{C}$, the peak at $1030-1060 \mathrm{~cm}^{-1}(v(\mathrm{Si}-\mathrm{O}))$ remains broad despite the evidence of crystallization in the $\mathrm{XRD}$ at $500^{\circ} \mathrm{C}$. However, at $700^{\circ} \mathrm{C}$, where considerable recrystallization is observed by $X R D$, this broad peak splits and sharpens, as do all of the other peaks in this region of the spectrum. At $900^{\circ} \mathrm{C}$, peak resolution and narrowing continue. The band at $\approx 1100 \mathrm{~cm}^{-1}$ is the asymmetric $v(\mathrm{Si}-\mathrm{O}-\mathrm{Si})$, while the band at $\approx 970 \mathrm{~cm}{ }^{-1}$ is due to $v\left(\mathrm{Si}-\mathrm{O}^{-} \mathrm{Cs}^{+}\right)$. The bands at $\approx 700$ and $760 \mathrm{~cm}^{-1}$ may be attributed to symmetric $v(\mathrm{Si}-\mathrm{O}-\mathrm{Si})$ vibrations.

\section{Conclusions}

The TGA decomposition studies indicate that the monomeric glycolato silicates dimerize at approximately $200-220^{\circ} \mathrm{C}$. In all instances, the TGA found ceramic yields were, within experimental error, the same as the calculated ceramic yields if $\mathrm{M}_{2} \mathrm{Si}_{2} \mathrm{O}_{5}$ is assumed to be the product. These results are a good indication of the purity of the starting materials and the products. The primary weight losses for all of the glycolato silicates occur at temperatures between $335^{\circ} \mathrm{C}(\mathrm{Cs})$ and $395^{\circ} \mathrm{C}(\mathrm{Na})$ which corresponds to the region in which oxidative removal of the glycol ligands occurs. This then represents the temperature window that defines the precursor to ceramic transition. It also defines a likely processing window for polymeric derivatives that can be made by substitution with tetraethylene glycol. ${ }^{1.29}$

In the bulk decomposition studies, the decomposition pathway for all of the dimeric alkali glycolato silicates studied involves initial oxidative decomposition to an amorphous phase at $\approx 300^{\circ} \mathrm{C}$, as determined by both the DRIFTS spectra and XRD patterns. Even though the bulk decomposition studies are run in flowing, dry air, at least part of the $\mathrm{CO}_{2}$ produced during ligand oxidation is captured by the intermediate pyrolysis products. $\mathrm{CO}_{2}$ capture leads to the formation of both the alkali metal carbonates and, if exposed to moisture, bicarbonates.

With the exception of the lithium product, which crystallizes, all of the intermediates pyrolyzed to $500^{\circ} \mathrm{C}$ remain amorphous and exhibit at least some evidence for the presence of carbonate species. With the exception of the potassium product, all of intermediates form crystalline products by $700^{\circ} \mathrm{C}$ wherein one phase, the disilicate $\mathrm{M}_{2} \mathrm{Si}_{2} \mathrm{O}_{5}$, predominates. The potassium product crystallizes, but gives three distinct products that are the result of segregation. ${ }^{3}$ At $900^{\circ} \mathrm{C}$, all of the products are crystalline except the $\mathrm{Na}_{2} \mathrm{Si}_{2} \mathrm{O}_{5}$ product, which melts.

These studies indicate that with the exception of the potassium glycolato silicate, it is possible to transform $\mathrm{M}_{2} \mathrm{Si}_{2}\left(\mathrm{OCH}_{2}-\right.$ $\left.\mathrm{CH}_{2} \mathrm{O}\right)_{5}$ (where $\mathrm{M}=\mathrm{Li}, \mathrm{Na}$, or $\mathrm{Cs}$ ) into the corresponding disilicate with little or no interference from secondary phases, although at lower temperatures the formation of carbonate does occur. Currently, no clear-cut explanation exists for why bulk pyrolysis of the potassium salt leads to partial segregation, although it may be argued that the miscibility gap common for potassium silicates extends to the reaction temperatures used here.

The next step in these studies is to determine whether or not polymeric precursors prepared by exchange of ethylene glycol with longer-chain diols, ${ }^{1,29}$ and therefore contain more carbon, will behave in the same manner during pyrolysis. These studies will determine the utility of pentacoordinate alkoxysilicates for processing novel silicate glass (ceramic) shapes such as coatings, thin films, fibers, and membranes.

\section{References}

'R. M. Laine, K. Y. Blohowiak, T. R. Robinson, M. L. Hoppe, P. Nardi, J. Kampf, and J. Uhm, "Synthesis of Novel, Pentacoordinate Silicon Complexes from $\mathrm{SiO}_{2}, "$ Nature (London), 353, 642-44 (1991).
${ }^{2}$ K. A. Youngdahl, P. Nardi, T. R. Robinson, and R. M. Laine, "The Synthesis of Novel Penta-alkoxy and Penta-aryloxy Silicates from Silica," NATO Adv. Study Inst. Ser., Ser. E, 206, 99-114 (1991).

${ }^{3}$ C. R. Bickmore, M. L. Hoppe, R. M. Laine, K. A. Youngdahl, P. Nardi, T. R. Robinson, and J. Uhm, "Chemicals, Polymers and Ceramics from the Beach (Silica)"; pp. 663-71 in 5th International Conference on Ultrastructure Processing. Edited by L. L. Hench and J. K. West. Wiley, New York, 1992.

${ }^{4}$ C. Bickmore, M. L. Hoppe, and R. M. Laine, "Processable Oligomeric and Polymeric Precursors to Silicates Prepared Directly from $\mathrm{SiO}_{2}$, Ethylene Glycol and Base," Mater. Res. Soc. Symp. Proc., 249, 107-14 (1991).

'Z. F. Zhang, M. L. Hoppe, J. A. Rahn, S.-M. Koo, and R. M. Laine, "Low Temperature Routes to Cordierite-Like Ceramics Using Chemical Processing," Mater. Res. Soc. Symp. Proc., 249, 81-86 (1991).

${ }^{6}$ M. L. Hoppe, R. M. Laine, J. Kampf, M. S. Gordon, and L. W. Burggraf, "Barium Tris(glycolato)silicate, a Hexacoordinate Alkoxy Silane Synthesized from $\mathrm{SiO}_{2}$," Angew. Chem., Int. Ed. Engl., 32, 287-89 (1993).

${ }^{7}$ C. L. Frye, "Pentacoordinate Silicon Derivatives. IV. Alkylammonium Siliconate Salts Derived from Aliphatic 1,2-Diols," J. Am. Chem. Soc., 92, 1205$10(1970)$.

${ }^{8}$ C. L. Frye, G. A. Vincent, and W. A. Finzel, "Pentacoordinate Silicon Compounds. V. Novel Silatrane Chemistry," J. Am. Chem. Soc., 93, 6805-10 (1971).

"R. R. Hoimes, R. O. Day, J. J. Harland, A. C. Sau, and J. M. Holmes, "A Pseudorotational Coordinate for Five-Coordinated Silicon. Synthesis and Molecular Structure of Cyclic Anionic Silicates Isoelectronic with Phosphoranes," Organometallics, 3, 341-47 (1984)

"'R. R. Holmes, R. O. Day, J. J. Harland, and J. M. Holmes, "Synthesis and Molecular Structure of Hydrogen-Bonded Cyclic Anionic Silicates with Phosphoranes. Structural Principles of Five-Coordinated Silicon," Organometallics, 3, 347-53 (1984).

'A. Boudin, G. Cerveau, C. Chuit, R. Corriu, and C. Reye, "Reactivity of Anionic Pentacoordinated Silicon Complexes towards Nucleophiles," Angew. Chem., Int. Ed. Engl., 25, 473-76 (1986).

"M. Kira, K. Sato, C. Kabuto, and H. Sakurai, "Preparation and X-ray Crystal Structure of the First Pentacoordinate Silylsilicates," J.Am. Chem. Soc., 111, 3747 (1989).

${ }^{13}$ (a) K. Y. Blohowiak, M. L. Hoppe, K. W. Chew, B. Mueller, C. L. S. Scotto, T. Hinklin, F. Babonneau, J. Kampf, and R. M. Laine, "SiO ${ }_{2}$ as a Starting Material for the Synthesis of Pentacoordinate Silicon Complexes. I"; unpublished work. (b) P. Kansal and R. M. Laine, "Hexacoordinate Silicon Complexes as Precursors to Silicon Containing Ceramics"; unpublished work.

${ }^{14}$ R. Puyane, P. F. James, and H. Rawson, "Preparation of Silica and Soda-Silica Glasses by the Sol-Gel Process." J. Non-Cryst. Solids, 41, 105-15 (1980).

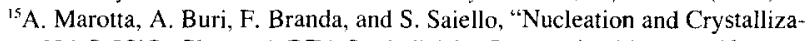
tion of $\mathrm{Li}_{2} \mathrm{O} \cdot 2 \mathrm{SiO}_{2}$ Glass-A DTA Study," Adv. Ceram., 4, 146-52 (1982).

${ }^{16}$ (a) Sadtler High Resolution Spectra of Inorganics and Related Compounds. Sadtler Research Laboratories, PhiladeIphia, PA, 1965. (b) D. R. Lide (Ed.), Handbook of Chemistry and Physics, 71 st ed.; p. 4-74. CRC Press, 1990-91. (c) J. W. Mellor, Supplement to Mellor's Comprehensive Treatise on Inorganic and Theorefical Chemistry, Vol. II, Supplement II, The Alkali Metals, Part I; pp. 250-55. Wiley, New York, 1963. (d) M. D. Haidar, M. A. Aziz, and P. A. Langer, "On the Preparation and Composition of the Acid Carbonates of Alkaline Earths and Lithium," J. Indian Chem. Soc., 21, 178 (1944).

${ }^{17} \mathrm{We}$ thank one of the reviewers for bringing to our attention the fact that the bicarbonates decompose below our lowest pyrolysis temperature of $300^{\circ} \mathrm{C}$.

${ }^{18}$ T, Uchino, T. Sakka, K. Hotta, and M. Iwasaki, "Attenuated Total Reflectance Fourier-Transform Infrared Spectra of a Hydrated Sodium Silicate Glass," J. Am. Ceram. Soc., 72, 2173-75 (1989).

${ }^{15} \mathrm{~F}$. Domine and B. Piriou, "Study of Sodium Silicate Melt and Glass by Infrared Reflectance Spectroscopy," J. Non-Cryst. Solids, 55, 125-130 (1983).

"IT. Uchino, T. Sakka, and M. Iwasaki, "Interpretation of Hydrated States of Sodium Silicate Glasses by Infrared and Raman Analysis," J. Am. Ceram. Soc., 74, 306-13(1991).

${ }^{21}$ S. A. Brawer and W. B. White, "Raman Spectroscopic Investigations of the Structure of Silicate Glasses. I. The Binary Alkali Silicates," J. Chem. Phys., 63 [6] 2421-32 (1975).

${ }^{22}$ S.-P. Szu, M. Greenblatt, and L. C. Klein, "X-ray Diffraction and ${ }^{29}$ Si NMR Study of Polymerized and Infiltrated Lithium Silicate Gels," J. Non-Cryst. Solids, 124, 91-100 (1990).

W. F. Hammetter and R. E. Loehman, "Crystallization Kinetics of a Lithium Silicate Glass-Ceramic," J. Am. Ceram. Soc., 70, 577-82 (1987).

${ }^{24} \mathrm{~N}$. Milestone; private communication.

J. D. Mackenzie, I. Brown, and P. Ranchod, "Silicate Bonding of Inorganic Materials," I. Mater. Sci., 26, 769-75 (1991).

${ }^{26} \mathrm{~F}$. Babonneau, P. Kansal, and R. M. Laine; unpublished results.

"C. M. Schramm, B. H. W. S. de Jong, and V. E. Parziale, "29 Si Magic Angle Spinning NMR Study on Local Silicon Environments in Amorphous and Crystalline Lithium Silicates," J. Am. Chem. Soc., 106, 4396-402 (1984).

${ }^{2 x}$ J. F. Stebbins, "NMR Evidence for Five-Coordinated Silicon in a Silicate Glass at Atmospheric Pressure," Nature (London), 351, 638-39 (1991).

${ }^{29} \mathrm{~K}$. W. Chew, B. Dunn, T. A. Faltens, M. L. Hoppe, R. M. Laine, T. R. Robinson, and C. S. Scotto, "Ion Conducting Polymers Synthesized in One Step from $\mathrm{SiO}_{2}$ "; unpublished work. 